\title{
IRRIGATION AND LAND-RECLAMATION HISTORY OF UZBEKISTAN (As an example of the 50-80s of $X X$ century)
}

\author{
Oybek Kamilovich Komilov \\ Professor at the department of "Theory of civil society" of Andizhan State University, Doctor of \\ Science in History, Andizhan, Uzbekistan \\ Khabibullo Kuchkarov \\ Assistant professor at the department of "Economy" of Andizhan State University, PhD in Economics, \\ Andizhan, Uzbekistan
}

Article DOI: https://doi.org/10.36713/epra3988

\begin{abstract}
Based on solid scientific literature and archival sources, the article comprehensively reveals the history of irrigation and land reclamation in 1950-1980 in Uzbekistan to further expand irrigation networks in order to plant a monoculture of cotton in the republic, as well as its consequences.

KEY WORDS: irrigation, irrigation canal, pumping station, siphon, collector, drainage, Soviet government, centre, cotton monopoly.
\end{abstract}

\section{INTRODUCTION}

Irrigation in Uzbekistan has always been important for the national economy. Therefore, the strategic vision of the President of the Republic of Uzbekistan Sh.Mirziyoev is the Ministry of Agriculture and Water Resources of the Republic of Uzbekistan, companies and other agencies, khokimiyats of all levels $[1, \mathrm{p} .41]$. the use of issues is of particular importance. Yet, in the period of the Soviet authority, it was aimed to build a colonial and tyrant society in Uzbekistan. First of all, the administrators paid attention to the development of agriculture in the Republic. Because Uzbekistan being within the former Union specialized to grow cotton, became the source of raw material and $3 / 2$ of the cotton was carried to the center in carrying out it, water and irrigation were important. According to the colonial character of the agrarian policy of the Soviet authority, irrigation and land-reclamation of the Republic developed intensively.

\section{METHODS}

Increasing irrigation and land-reclamation became the most important in setting up the national economy of the Republic after the war. The first five-year period after the war was carried out successfully, at the result of national set up and development a lot of achievements were gained in the sphere of the cotton growing which was considered the main branch of agriculture[5, 159]. Within 1946-1950 cotton fields widened from 815,6 thousand hectares to 1098,1 thousand hectares, the total cotton harvest rose to 2226 thousand tons from 1118 thousand tons[6, 21].

During the postwar years the successes and achievements of irrigation only served to the collective farms. First of all, water was spent to irrigate cotton fields. Grain, vegetable, orchards and other sowing areas were irrigated secondly. Because of water deficiency private family lands remained without water $[4,45]$.

According to the decree №1791, October 11, 1950 of the Ministers' Council of Uzbekistan SSR, it 
was emphasized that "the chairman of Surkhandarya irrigation department, K.Y.Yakubjanov was responsible for the construction of a bridge over the "Zang" canal within May 1 and August 1, 1951 and providing it with material and workers"[11]. There were 253 thousand hectares of land worthy to irrigating agriculture in Surkhandarya province of Uzbekistan SSR in 1950. Nowadays 130 thousand hectares of it is irrigated [12]. The lands being reclaimed in Sariasiya, Denov and Shurchi, which are considered high group districts, are irrigated with the water of the Koratog, Dashnabad, Tupolang, Sargardak and Khujaypak rivers. Irrigation sowing area is 30 thousand hectares there.

The Ministers' Council of Uzbekistan SSR worked out a decree №234 on February 8, 1951 "On preparing irrigation systems to the spring of 1951" [13]. According to this decree it was noted by the Ministers' Council of Uzbekistan SSR that in many provinces of the Republic preparation of the irrigation systems to the spring of 1951 was absolutely dissatisfying. Cleaning irrigation and collector-drainage system, preparing irrigation system to the irrigating company were considered one of the main measures, and only $35 \%$ of it was carried out in the Republic. Particularly, cleaning was dissatisfying for 21\% in Karakalpakistan SSR, 23\% in Andijan province, $25 \%$ in Samarkand. Division of workers by the schedule was not organized accurately. Within the last 5-day-period only 136 thousand people worked instead of 472 thousand throughout the Republic.

\section{RESULTS AND DISCUSSIONS}

A decree "on the process of the reconstruction of irrigation structures and changing into new irrigation system" was worked out by the Ministers' Council of Uzbekistan SSR on March 13, 1952. In the decree party and council bodies of the Republic admitted that reconstruction ditches and changing into new irrigation system had been fulfilled dissatisfying. The information about the lacks in changing into the new irrigation system was noted as following in the decree: "Only 187 thousand hectares have been changed into the new irrigation system instead of 589 thousand hectares, in other words, $34,6 \%$ of the plan has been fulfilled by the March 10 of this year. 30 thousand hectares of land has been changed into the new irrigation system instead of 85 thousand hectares. $23,3 \%$ of the changing into the new irrigation system plan has been fulfilled in Khorezm province. Reconstruction of irrigation ditches and enlargement of irrigation areas are particularly being run unsatisfactorily in Karakalpakistan SSR and in cotton growing state farms"[14].

Based on the above mentioned decree the Ministers' Council of Uzbekistan SSR and C(b)P
Central Committee worked out the decree №507 “on holding a fortnight for changing into the new irrigation system" on March 17, 1952. In order to hasten the reconstruction of the irrigation ditches and changing into the new irrigation system the Ministers' Council and $\mathrm{C}(\mathrm{b}) \mathrm{P}$ Central Committee of Uzbekistan SSR adopted a resolution as following:

1. The decree of the Ministers' Council of the USSR on March 13, 1952, "On the process of the reconstruction of irrigation systems and changing into the new irrigation system in Uzbekistan SSR" shall be accepted to use and execute.

2. The Minister of the cotton growing of Uzbekistan SSR Nasirov, Minister of agriculture Gulomov, Minister of irrigation Alimov, the secretaries of province party committees and the chairmen of province executive committiees: Makhmudov and Fayzullayev in Tashkent province, Pakhmanov and Davlatov in Khorezm province, Makhmudov and Japakov in Karakalpakistan SSR shall attract their attention that the fulfillment of the Ministers'Council of Uzbekistan SSR and C(b)P Central Committee of Uzbekistan "on holding a fortnight for changing into the new irrigation system" is a serious situation.

On September 6, 1952 the USSR Cotton growing Ministry worked out a decree №1691 “On unsatisfactorily using irrigating lands in Uzbekistan SSR" [15].

The causes and results of dissatisfying fulfillment of the preparation plan of the unused lands in the irrigation field consisted of the following:

- Not paying enough attention and time to the matter of land-reclamation, irrigation institutions didn't head properly to the irrigation-land-reclamation preparation of virgin lands and carried out work independently from the cotton growing and irrigation institutions;

- Not having been ordered in time by the cotton growing institutions to the irrigation-landreclamation preparation of unused lands in the irrigation field;

- Not to pay an adequate attention to the workers, to the dissatisfying usage of workers and mechanisms for the preparation of irrigation-landreclamation.

In order to solve the above mentioned shortage and to provide the fulfillment of the reclamation plan of the unused lands in the irrigation field and to improve the new irrigation constructions for 1953 Karakalpakistan ASSR Irrigation minister and the chairmen of provincial irrigation departments were ordered the following: 
- To the Karakalpakistan ASSR Irrigation minister and to the chairmen of provincial irrigation departments;

- According to the decree №1691 on September 6, 1952 of the USSR Cotton growing Ministry, Nasirov, the minister of Uzbekistan SSR Cotton Growing, was obliged to work out the task of irrigation-land-reclamation preparation of the lands in the irrigation field, to give it to the regional irrigation branches, and to give instructions by map and nature.

Irrigation-land-reclamation developed in the Republic in the 50-60s of XX century. The main purpose of the Soviet Government was to enlarge cotton fields and to increase cotton harvest by developing these fields. A special attention was paid by the tyrant authority to the irrigation construction in the republic, and division of financial means for it also increased year by year. A lot of irrigation structures were constructed to irrigate sowing fields and huge areas. For instance, "a great irrigation work was carried out in the Surkhan-Sherabad desert too-the southern zone of the republic. There was 145 hectares of empty land area worthy irrigating there. From 1955 to the January of 1958, 21423 thousand $\mathrm{m} 3$ land and 16825 $\mathrm{m} 3$ concrete and iron-concrete laying works for the hydro technic structures were carried out there. And it gave the opportunity to improve provision of irrigating areas with water and irrigating ten thousand hectares of new lands" [8, 49]. In the Soviet authority period the size of irrigating areas enlarged year by year. For instance, the increase of irrigating areas in Uzbekistan in 1950-1986 was reflected in the following table.

Table 1

Dynamics of the irrigating area increase in Uzbekistan, (1000 hectares)

\begin{tabular}{|c|c|c|c|c|c|c|}
\hline Years & $\mathbf{1 9 5 0}$ & $\mathbf{1 9 6 0}$ & $\mathbf{1 9 7 0}$ & $\mathbf{1 9 8 0}$ & $\mathbf{1 9 8 5}$ & $\mathbf{1 9 8 6}$ \\
\hline $\begin{array}{c}\text { thousand } \\
\text { hectares }\end{array}$ & 2276 & 2964 & 2696 & 3476 & 3930 & 4020 \\
\hline
\end{tabular}

CPCC of Uzbekistan and the Ministers' Council of Uzbekistan SSR determined the following in decree №76 on February, 1961 [17] "on reclaiming measures of the new lands on the basin of Surkhandarya under the base of Surkhan water reservoir concerning irrigation and farming":

1. "The chief plan of agricultural reclaiming and irrigating the new lands of Surkhandarya province in Uzbekistan SSR under the base of the Southern Surkhan water reservoir" worked out by "Sredashydrovodhlopok" institution was approved and 356 million roubles of capital means were separated to carry out it. This sum was divided in the following way: 161 million roubles for the construction of irrigation structures, 110 million roubles for the organization of state farms, 25 million roubles for external communications, 22 million roubles for the construction of industrial enterprises and base, 38 million roubles for the farm reclamation. 280 million of the sum was for the most important tasks.

2. The plan of preparation 86,3 thousand hectares of the new lands under the Southern Surkhan water reservoir in Surkhandarya province in the 7-year period was approved. The plan was carried out for 0,5 thousand hectares in 1959, 3,3 thousand hectares in $1961,11,1$ thousand hectares in 1962, 20,6 thousand hectares in 1963, 25 thousand hectares in 1964, 25,8 thousand hectares in 1965. The division plan of it concerning irrigation systems and farming sectors was reflected in the following table.

Table 2

Preparation plan of new lands in Surkhandarya province under the base of the Southern Surkhan water reservoir (1959-1965)

\begin{tabular}{|c|c|c|c|c|c|c|c|c|c|c|}
\hline № & $\begin{array}{c}\text { Names of } \\
\text { objects, systems }\end{array}$ & $\begin{array}{c}\text { Farms that } \\
\text { reclaim } \\
\text { the lands }\end{array}$ & $\begin{array}{c}\text { Total in } \\
\text { the 7-year } \\
\text { period }\end{array}$ & 1959 & 1960 & 1961 & 1962 & 1963 & 1964 & 1965 \\
\hline 1 & Zangan system & $\begin{array}{l}\text { State } \\
\text { farms }\end{array}$ & 34,0 & - & - & 2,0 & 8,0 & 15,0 & 9,0 & - \\
\hline 2 & $\begin{array}{c}\text { Sherabad } \\
\text { system }\end{array}$ & $\begin{array}{c}\text { State } \\
\text { farms }\end{array}$ & 41,8 & - & - & - & - & - & 16,0 & 25,8 \\
\hline 3 & Left bank canal & $\begin{array}{c}\text { Collective } \\
\text { farms }\end{array}$ & 10,5 & 0,5 & - & 1,3 & 3,1 & 5,6 & - & - \\
\hline \multicolumn{3}{|c|}{ Total } & 86,3 & 0,5 & - & 3,3 & 11,1 & 20,6 & 25,0 & 25,8 \\
\hline
\end{tabular}


As it is known by the statistics in the table, the preparation of the new lands to the reclamation under the base of the Southern water reservoir in Surkhandarya province increased year by year. The preparation of the new lands for the reclamation in Sherabad system was not organized well in 1959-1963 of the 7-year period.

As well as, the construction of 10 state farms were organized in the irrigating areas in 1962-1967. In 1962-1964 3 state farms, clearly, state farms №1, №2, №3, in 1963-1965 state farms №4, №5, №6, in 19641966 state farms №7, №8, №9 and one state farm garden were organized.

According to the plan 550 thousand roubles of sum was separated for the reconstruction of Urtatukay water reservoir by the building organizations by September 1, 1962, but in practice, it was carried out for 109,8 thousand roubles in sum, in other words, for $20 \%[18]$. And it means that the work had not been organized in high level. Basing on the decree №718 "on the measures of enlarging irrigation areas and improving irrigation system techniques in Samarkand, Bukhara and Kashkadarya provinces, increasing provision of irrigation areas with water" by the CP CC of Uzbekistan and the Ministers' Council of Uzbekistan SSR on December 21, 1964, the Irrigation Ministry of Uzbekistan SSR proclaimed order №3 on January 6, 1965.

"Sredashydrovodhoz" institution was responsible for the formation of the project on reclaiming the lands of mid Kashkadarya by December 1,1965 , for the construction of the canals with pumping stations on both banks from the Chimkurgan water reservoir, for generalizing working drafts of general work capacity in 1966 [19].

On the base of above mentioned order, CP of Uzbekistan accepted the proposal of Kashkadarya Committee and executive committee of the province. The proposal included the following:

- On the organization of state farms specialized to cotton growing under the base of "Kukdala" state farm lands and in the down part of "Ulus" state farm irrigated with "Eski Angor" canal;

- The proposal on working out one level project for irrigating one thousand hectares of new lands of "Kukdala" state farm with "Eski Angor" canal by "Sredashydrovodhoz" institution by December 30, 1964 and the other proposals were considered.

According to the above mentioned decree №718 "on the measures of enlarging irrigation areas and improving irrigation system techniques in Samarkand, Bukhara and Kashkadarya provinces, increasing provision of irrigation areas with water" by the CPCC of Uzbekistan and the Ministers' Council of
Uzbekistan SSR the Ministry of production and preparation of agricultural products of Uzbekistan SSR worked out order №72 on February 6, 1965[20].

According to this order:

- F.I.Musin, the chairman of the department of growing and preparation agricultural products, was responsible for enlarging irrigating areas in Kashkadarya province, as well as, organization of a state farm specialized to cotton growing and name it "Eski Angor", a state farm named after Okhunbabayev in the territory of Chirokchi production department base, accommodation of new "Eski Angor" state farm in the territory of department 3 and "Kuk dala" state farm, and organization 5800 hectares of sowing areas, 3400 hectares of irrigating area, and 3000 hectares of cotton fields. In addition to it:

- Organization of "Eski Angor" state farm on the scheme of "Uzgiprozem";

- Forming production finance plan of "Eski Angor" state farm and presenting it according to the existing regulation.

To the departments of capital construction and irrigation and land-reclamation (N.D.Berger):

- To work out project task of "Uzgiprozem" institution planned to 1965 on the organization of "Eski Angor" state farm and to take it into consideration in the project-exploring work;

- According to existing project-budget documents dividing capital means limits for the irrigation construction, cultural-economic, accommodation and production for 1965 [9].

The Ministry of production and preparation of agricultural products of Uzbekistan SSR worked out order № 98 on February 19, 1965 in accordance with the decree №93 on February 9, 1965 “on increase measures of providing irrigating areas of Uzbekistan SSR in 1965 with water" by the Ministers' Council of Uzbekistan SSR. As the Ministers' Council of Uzbekistan SSR noted, it was expected that water spending was in rather low norm during the vegetation period in 1965 .

According to the decree of the $\mathrm{CP}$ CC of Uzbekistan and the Ministers' Council of Uzbekistan SSR on September 23, 1976 "on the reclamation plan in 1976-1980 and increase measures of using reclaimed lands", Namangan province irrigation and construction organizations completed the plan on reclaiming new lands [10]. In the $10^{\text {th }} 5$-year time period 18,4 thousand hectares of the new irrigating area was presented to use in the province, land-reclamation condition of 33,8 thousand hectares of land was improved.

In 1986-1990 it was necessary to reclaim 17 thousand hectares of land, to improve water provision in 40 thousand hectares, to improve land-reclamation 
condition of 38 thousand hectares, and it's necessary to smooth 45 thousand hectares of land ploughed every year. On this occasion a great irrigation-landreclamation work was being carried out $[7,5]$. During four years and 9 months of the $10^{\text {th }} 5$-year time period 207,6 thousand hectares of new irrigating lands began applying and the land-reclamation of 454,7 thousand hectares of land improved [2, 17].

According to the plan of 198126 landreclamation facilities cost 38,1 million roubles, planned to construct in Karakalpakistan ASSR. 6,7 million of the 30,4 million roubles of the reminder sum on January 1, 1981, inserted into the plan. From January to August the plan was carried out for 2,7 million roubles in $\operatorname{sum}(40 \%$ according to the annual plan). In 1980 landreclamation fund of the irrigation farms was 3145 million roubles. The irrigation system of the Republic was equipped with new hydro-technic structures, in other words, it rose for 6,9 thousand hectares. The number of the hydrometric constructions rose to 2,5 thousand. In 1981 the Ministry of Irrigation of UzSSR determined the order on complex-reconstructing irrigation system in 10 thousand hectares. In order to carry out it, it was considered to divide 14,2 million roubles of capital means for it. From January to August 4,1 million roubles was acquired (29\%), 2095 hectares was submitted. The fulfillment of these works was more satisfactory in Khorezm province than others. According to the plan 1264 hectares of 3151 hectares was submitted there ( $40 \%$ by the annual plan).

Because of the irrigation construction in the Republic in 1981-1990, the number of working water reservoirs reached 23. The construction of 15 of them continued, and projecting 6 of them ran $[3,129]$.

\section{CONCLUSION}

As a conclusion it is fair to emphasize that in 50-80 of the XX century irrigation developed in Uzbekistan in accordance with the agrarian policy of the Soviet authority. The development of irrigation and establishment of cotton monopoly in the Republic caused to lots of critical aspects. This policy, particularly, increased the dependence of the Republic to the center on the provision of people with grain and food-stuffs. As irrigation-land-reclamation developed highly at the result of cotton monopoly in the republic the land began to lose its fertility, deficiency of water resources increased year by year. As well as, at the result of reclaiming virgin lands, organization of many districts, state farms specialized to cotton growing, enlarging cotton fields and irrigating them improperly, not using water resources incorrectly there occurred serious problems like water deficiency. The irrigation structures built to develop cotton growing together with its positive sides caused some critic aspects. Improper use of water resources, irrigating large sowing areas incorrectly, reclamation of virgin lands, organization of districts and state farms in those areas, at last, caused to water deficiency as well as to the Aral tragedy.

\section{REFERENCES}

1. Mirziyoev Sh.M (2017). Critical analysis, strict discipline and personal responsibility must be the daily routine of each leader's activities. January 14, 2017 Report of the Cabinet of Ministers on the main results of socio-economic development of the country in 2016 and the key priorities of the economic program for 2017. - Tashkent: Uzbekistan,-p.41.

2. Afonin D.I (1981). Industrialization of repairexploitation work, submitting dispatch and automation control of the irrigation systems in Uzbekistan SSR// Express-information "landreclamation and irrigation". Series 6, edition 9.-M., p.17-26.

3. Akramov Z.M., Rafikov A.A (1990). The Past, Present and Future of the Aral Sea-Tashkent: Mekhnat, p.142.

4. Andizhan province state archive (APSA), fund-608, list 1, case 1633, p.83.

5. Egamberdiyev R, Razzakov A (1984). The history of irrigation, land-reclamation and land-improvement in Uzbekistan (in the example of Mirzachul).Tashkent: Fan. p.285.

6. Jabbarov $N$ (1968). Irrigation development in Uzbekistan and its future.-Tashkent: Fan, p.279.

7. Kasimov Y (1988). From the irrigation history of Namangan oasis.-Tashkent: Fan, p.121.

8. Namangan province state archive (NPSA), fund275, list 1, case 3620, p.1.

9. Ochilov $N$ (1991). Irrigation-land-reclamation in Uzbekistan (1946-1964).-Tashkent: Fan, p.104.

10. Tsamutali A.S (1972). Problems of extensive production in the cotton-growing collective farms of Uzbekistan: Tashkent, Fan, p.135.

11. National Archive of the Republic of Uzbekistan,( NARUz), fund-R.2483, list 1, case 682, p.29.

12. NARUz, fund-R.2483, list 1, case 705, p.29.

13. NARUz, fund-R.837, list 38 , case 20, p.79.

14. NARUz, fund-R.837, list 38, case 3803, p.234.

15. NARUz, fund-R.2483, list 1, case 746, p.14.

16. http//www.igpi.ru/bibl/igpi_publ/uzb_eco.html// Gayevaya T.Ya., Pisareva V.N. Ecologic situation in Uzbekistan.

17. NARUz, fund-R.2483, list 1, case 1595, p.289.

18. NARUz, fund-R.2483, list 1, case 1993, p.142

19. NARUz, fund-R.2483, list 1, case 1010, p.60.

20. NARUz, fund-R.2483, list 1, case 1010, p.70. 